\title{
A Political Economy of the African School as a Learning Organization
}

\author{
AOK Noah PhD, \\ Lagos state University, Ojo, Lagos Nigeria. \\ E-mail: aoknoah@gmail.com
}

Accepted: January 5, 2012 Published: April 14, 2012

Doi:10.5296/ijld.v2i2.1632 URL: http://dx.doi.org/10.5296/ijld.v2i2.1632

\begin{abstract}
Total enterprise and the marketization of schooling as implied and currently practiced hold no good for the poor African child. The poor African needs to be protected from the consequences and excesses of the free market. The paper concludes that learning organization is a pseudonym for marketization and intellectual pauperization.
\end{abstract}

\section{Introduction}

Schools are a significant part of industrial and post-industrial human societies, they reflect their environments, strengthen contemporary adaptation processes and needs, and help secure the future. However as knowledge and information technology advance and change the nature of business, finance, politics etc, the question arises as to whether or not schools have been insulated from the types of changes that other institutions have recently undergone or experienced, how much of a learning organization the school is and how much of class bias is in this. In this work, the focus is on the Nigerian school as a learning organization and the dialectics of the social relations of production inherent in this. The methodology is the application of the political economy approach to the school and the social relations there.

\section{The New Metaphor}

Enterprise is the new metaphor for schooling in post-industrial societies. Schools must compete, must search and research and be chartered. Unlike in the colonial past when schools were managerially inactive and always dependent on government's directives and supervision, twenty-first century schools are internally, self-driven and often profit oriented. The impact of enterprise and the profit bias is found in the situation whereby in several African states schools are often of two types: public and privately owned schools. Public schools still live in the past, dependent on the government and lacking basic equipment and facilities, while 
private schools are entrepreneurially driven, with better basic facilities and equipment and charging fees determined by their proprietors (and management).

The consequence is that in several African states, the (good) private school is priced out of the reach of the lower class. Whereas in Africa schools of today are not generally different from those of the immediate post-independence era, in the west, the international trend towards devolution of many of the decisions and responsibilities for managing schools to the school itself-with the end-point being self-managing or self governing public schools has been perhaps the most powerful influence changing the understanding of the management of education over the past two decades. |'Instances can be seen in Canada, where the Edmonton school district pioneered many of the features we see today; in the United Kingdom, with grant-maintained (GM) and locally managed (LM) schools, in the United States, with the charter-school movement; and in New Zealand, which adapted the Canadian model as a means for developing a natural system of self-managing schools called schools of tomorrow' (Townsend 1998: xx).

Enterprise has moved the world of education into the world of business and has institutionalized a 'user-pay scheme' which in Africa further strengthens the divide between the rich and the poor. The scheme is characterized by the reality that the people who most needed the service could not afford to pay and those that could afford to pay did not need the service. The consequence is that governments become or pretend to become less anxious to fund them on the basis that no one uses this service. Enterprise has also led to the introduction of 'productivity efficiencies' which is a short way of saying that although the number of those using the service (hospitals, tertiary education) increase substantially the increase in funding lagged far behind. In Africa, these changes are a destabilizing force within the public school systems; they constitute a mental administrative headache/crisis because fund-starved government owned schools are expected to compete with each other and the private schools simultaneously. The consequence is they are unable to perform due to the inability to reconcile an inadequate feudal funding pattern with post-industrial requirements, procedures and accountability patterns.

The public vs. private school mentality in Africa is a danger to public schooling and society. Public schools do only a core of state-mandated curriculum requirements while private schools do a 'core plus curriculum' whereby based on the needs of the children from the paying social class and parents, additional items and activities are put on to the curriculum. The rise of the market economy really purples a market dominated education and the poorer children suffer when things go wrong.

The new global ideology is to regard schools as enterprises not as places to confer privilege, not as factories, not as social welfare outlets, not as part of the fabric of a big civil-service bureaucracy' (Beare 1998: 13). In this atmosphere, government should steer rather than row, schools should earn where they can and not merely spend, schools should satisfy the customer not the bureaucracy, schools should achieve results 'No one will be particularly concerned 
abo:12), each school should define what it intends to do and be held responsible for carrying it out rather than being required to follow a rule book of government regulations, competition is the only incentive which works, monopolies corrupt especially among service givers, competition implies choice-customer choice-and choice implies variety; and the school and the system should shape their processes and services so that the incentives arise naturally from the way the enterprises is situated in the community. The magnifications and implications are that: most money allocated for education will go straight from government to individual schools, support services must be privatized, schools gain increased legal and professional responsibilities in the form of a global budget, wide discretion over funding, the responsibility to select their own staff and fill their promotion position from the principal down, the management and upkeep of their physical plant, and the government empowers schools, rather than serve then, usually through some legislation or devolution.

A consequence of enterprise and marketization is the bastardization of the backbone of schooling, which is the curriculum. The curriculum is now re-imaged as a pathway (no longer a course of study) what is to be learnt, occupies more attention than the learner, schooling is no longer individual, it is commoditized and disheveled into concerns about graduation, credentialism, standards and employability. Progressive education is treated as abberant, wrong and a passe'. Whereas the government will provide education in lower class areas because no one wants to, the private schools in middle and upper class areas are likely to receive split-level funding from a plurality of financing bodies, public schools, to governments, would become ;provisions of last resort'.

Another consequence of marketization and the death of progressive education is the comparatively low enrolment of students in science and technology courses. In the words of Bill Clinton (2007:76) 'America is facing a shortage of young people going into math, science and advance technology. If young women and African American and Hispanic men were to enter these fields at the same rate as Caucasian and Asian males, the shortage would be dramatically reduced or eliminated altogether' this is very difficult to achieve because those expected by this model to enter these fields are the African-Americans and Hispanics traditionally in the lower class and obviously discriminated against in the USA. The result is that marketization will always put the 'Kaffir' in his place.

Another solution, which is an indication of an adverse effect and failure of marketization, is to address the shortage of engineers and engineering technicians. The epitome is the launch in 2007 of a four-year effort to establish 110 academies of engineering in urban school districts across the USA designed to produce 8,800 high school graduates a year who will go on to college and careers in engineering and engineering technology. The project will emphasize increased participation of women and underrepresented minorities, preparing them for post-secondary studies by ensuring their competence in required mathematics, science and technical subjects (Clinton 2007:77).

In Nigeria the picture is not different when a look is taken at the pattern of admission into universities nowadays, "people are moving away too much from science, they are going into 
the services, the type of science that gets people excited now is communication technology. So to a large extent, most of our in take now are in the social and management sciences; economics, business administration and banking and finance" (Prof. Timothy Tayo, Vice-chancellor Caleb University, Lagos Nigeria, as reported in the Guardian Newspaper, Thursday September 2007).

Another adverse outgrow of the marketization of education is that individuals now have to dole out money to sustain schooling. For example the Bill and Melinda Gates Foundation have spent more than $\$ 1.7$ billion in the U.S to develop globally competitive high schools, while the Andre Agassi College Preparatory Academy Las Vegas, the Tiger Wood Learning Centre, in Anaheim California, and John Wood's Room to Read Project, established after a visit to Nepal in 1998, have been impactful.

To achieve equitable schooling in society, the solution would be neither in enterprise nor in marketization. As Bill Gates reportedly said "If we can find approaches that meet the needs of the poor in ways that generate profits for business and votes for politicians, we will have found a sustainable way to reduce inequity in the world' ( Clinton 2007:15).

\section{The Learning Organization,}

As the spirits of enterprise and marketization exert greater grips on schooling, school managers become business managers in strictly for profit organizations. The entrepreneurial drive demands that government educational enterprises should earn where they can, not merely spend while strictly for cash private schools must post good returns. Schools must watch their environment and become, in enterprise terms, learning organizations.

Learning organization is an organizational model characterized by a flat structure and customer-focused teams that engenders the collective ability to develop shared vision by capturing and exploiting employees' willingness, commitment and curiosity.

Peter Senge brought the concept back to public opinion in the 1990s and describes it as an organization with the capacity to shift away from views inherent in a traditional hierarchical, organization towards the ability of all employees to challenge prevailing thinking and gain a balanced perspective.

Senge believes five major elements of a learning organization are mental models, personal mastery, systems thinking, shared vision, and team learning. (The concept of the learning organizational was proposed by Chris Arguris and Donald Sehon as part of their work on organizational learning. (Bloomsbury Business 2002: 1276).

Creating a learning organization becomes particularly important in the post-industrial competitive schooling environment because the environment is becoming increasingly unpredictable, dynamic, and interdependent. The onus (for success) however is on leadership: an intellectually alert and proactive leadership is a sine qua non because the principal or leader 
must strive to harness the individual and collective talents of individuals throughout the entire organization. In a story by Charles Hardy, a company's courier refused to make a paid call to the addressee of a mail despite 5 calls to his base, because the cost would not be refunded and 'it shows how little they trust us' (Dess et al 2006: 374). This only shows that learning, information sharing, adaptation, decision making, and so on are not shared throughout the organization. Leading-edge organizations recognize the importance of having everyone involved in the process of actively learning and adapting. 'Clearly, everyone must be involved in learning; it can't be only a few people at the top of the organization. The key elements of a learning organization are inspiring and motivating people with a mission or purpose, empowering employees at all levels, accumulating and sharing internal and external information and challenging the status quo to enable creativity (Dess et al 2006: 362). The top no longer thinks while the local acts in organizations. No one can completely think it out at the top. The one who figures out how to harness the collective genius of the people in the organization wins the competition.

Learning organizations do four things. They do ongoing questioning of their status quo and procedures by asking all to reflect, they create a proactive, creative approach to the unknown, actively solicit the involvement of employees at all levels-higher-level skills are required of everyone not just those at the top, require employees to feel and support a compelling purpose and share values and pictures of the direction of the company. Peter Shenge (1993) wrote that shared vision is vital for the learning organization because it provides the focus and energy for learning.

According to Dess, Lumpkin and Eisner (2006: 375) there are four critical ongoing processes of learning organizations: empowering employees at all levels, accumulating and sharing internal knowledge, gathering and integrating external information, and challenging the status quo and enabling creativity.

Post industrial or learning organizations trust the intelligence and imagination of their workers, do not regard anyone as a loose canon, and canvass that in the information economy, the strongest organization are those that use effectively the talents of all the players on the team.

Effective organizations also redistribute information, knowledge (i.e. skills to act on the information), and rewards. Here everyone tells the truth everyday, not because everyone is honest but because everyone has access to the same information, operating metrics, financial data and valuation estimates.

The internet is the number one source of information these days. Company's also use 'Garden Variety' for the acquisition of external information for example by reading trade and professional journal. They also use benchmarking, whereby managers seek out the best examples of a particular practice as part of an ongoing effort to improve the corresponding practice in their own organization. These are of two primary types: competitive and functional (former restricted to competitors and later cover all known best practices regardless of 
industry). Also companies focus directly on customers for information (this helps reduce response time).

Learning organizations challenge the status quo, bring down political, behavioural system and personal time constraints in order to foster and promote creativity. They encourage a culture of intellectual dissent because 'gentle civility keeps the company from getting to the heart of a matter quickly. They take risks; cultivate cultures of experimentation and curiosity to make sure that failure is not, in essence, an offence. "people who stretch the envelope and ruffle feathers are protected.

More importantly, they encourage mistakes as a key part of their competitive advance and a mistake from intelligent risk is written off as tuition payment for the manager's education, thus implicitly everyone has a freedom to fail. The requirement for an open risk-tolerant culture, which is the opposite of the corporate culture of most organizations today, makes the learning organization to remain, for many thinkers, an unattainable deal.

The theory this far by Dess, Lumpkin and Eisner suggest that learning organizations recognize the individuals intellectual worth, are democratic, welcome intelligent failures in the pursuit of excellence, promote a culture of dissent, and monitor the knowledge/information environment. This could be very difficult to do in the near pre-industrial circumstances of African schools which constitute (anthropologically) a different corporate culture. It only reinforces Dibella and Nevis' (1997) emphasis that learning strategies will differ in different corporate cultures and that those differences are a source of competitive advantage.

\section{Errors in the Learning Organization}

Senge sees himself as an idealistic pragmatist who spends much time building learning organizations with the top leaders of companies, education and government and describes the learning organization as 'a group of people who are continually enhancing their capability to create their future by "changing individuals so that they produce results they care about, accomplish things that are important to them. 'Senge's basic premise can be stated very simply; people should put aside their old ways of thinking (mental models), learn to be open with others (personal mastery), understand how the company really works (system thinking), form a plan everyone can agree on (shared vision) and then work together to achieve that vision |(team learning)

The criticism of this model are that Senge is idealistic, his ideals are only in sight as there are few organizations that have been able to implement them successfully, most companies cannot afford the luxury of allowing their top executives to crash land for too long; breaking old corporate habits is very hard, and transforming into a learning organization is highly problematical as managers do not want to commit power and control suicides. In a blame-oriented culture, this change in attitude remains a major obstacle, (Bloomsbury 2002:1047). 
The circumstance or space of the African school contradicts the characteristics of the learning organization. The social milieu of the African school is anti-poor while the learning organization concept is western or at the best requiring or needing African adaptation. In Latin America and the Caribbean, students entering the teaching profession have a low academic profile and low socio-economic status compared to other students in higher education. There is some evidence that the socio-economic status of entering students has gone down over time. A study of applicants and graduates from the Pedagogical Institute of Chile between 1976 and 1992 shows that more than 80 percent of the students had aptitude entrance scores which were lower than students entering other professions (Gysling 1991, as reported in Wolff et $\underline{\text { al }}$ 1994: 71). The number of education students in Chile from low socio-economic sectors increased over the last fifteen years from $10.3 \%$ to $22.2 \%$. a study of Peru showed that students entering the teaching profession were often involved in work-study programmes, which generally attract low-income students unable to afford full time study.

In addition the catholic university of Peru has had to derive separate admission tests and requirements for students enrolling in education, since these entering students could not attain even the minimal general requirements for entrance which are generally met by students entering other profession (Wolff et al 1994: 72)

In several Sub-Sahara African (SSA) classrooms actual teaching time during the day may be quite low, with much of the school day occupied with routine and administrative matters. Specific teaching is in the presentation of expository materials to the entire class often through writing the content of the lesson, or explanations on the chalkboard, which is then copied by all children. The teacher uses this same methodology for all situations and audiences.

Though, most countries have an official calendar of 180 days, the actual number of school days in many cases is about 120 days, a result of a combination of holidays, teacher absences and strikes which may last a month or longer. One factor reducing the effective teaching time is the long distance rural teachers have to travel to and from the schools given that they often don't have housing or eating facilities nearly; little flexibility to replace ill teachers with substitutes; and the fact that teachers retire during the school year. In contrast, many individual teachers and schools in LAC use modern pedagogical techniques, with adequate teaching materials, and are achieving good results. The majority of these are in private fee-paying schools' (Wolff et al 1994: 77). However, several large scale experiments have shown that modern pedagogy can be introduced into public-financed primary schools and the result can be increased learning'. This shows that low socio-economic status children are not, as a group, less intelligent than their high socio-economic status counterparts. Those African schools needing increase in teachers salaries, reduced teacher-student ratios, better pedagogical practices, longer official calendar, classroom homogeneity, adequate teaching materials, and adequate teaching time, are obviously public schools for low socio-economic students, not private user-pay schools. 
Within the constrains imposed on public schools by government's poor funding and the impact of marketization, public schools in sub Saharan Africa have to strike a balance between becoming effective schools and being improved schools. The following factors determine school effectiveness: supporting inputs from outside the schools, enabling conditions, school climate and the teaching/learning process inside the school.

Schools improvement concentrates on how change occurs in the school system and its main themes are: effective leadership, share vision-building and support of school improvement permeating the organization at both the school and district levels, commitment and acceptance of school improvement efforts, active initiation and participation, changes in behavior and beliefs, collaborative planning and decision-making, organizational policies, support for action and press for improvement, staff development and resources assistance; monitoring efforts for accountability and recognition for jobs well done (Heneveld and Craig 1996: 13). However, with the low level of government funding and low morale among teachers, integration of school effectiveness and improvement prescription simply become ideals or a curious wish-list. Invariably many public schools in SSA become harambee (or self-help) schools, often with government-amputated parents/teachers associations, and students who do not expect much from their schools. The consequence is that 'one in two African children don't finish primary school, millions don't go at all. Those who do often end up in crowded schools with untrained teachers'.

In more than half of African countries, only 50 percent of children finish primary school and 12 percent complete high school. Only in a handful of countries-Botswana, Ethiopia, Seychelles, Sudan and South Africa- do more than 90 percent of primary students go on to high school. Even with the recent reform in Malawi, in Lilongwe at the Chiseka school on the outskirts of town, many children attend class outside, sitting among weeds, in the shade of a towering blue gum tree. There are 1, 531 students, six classrooms, no running water and no light bulbs. Yet Chiseka has the best academic record in the district. This pitiable state suggests that Africa has not reached the economic stage where she can surrender the education of her citizens to the vagaries of enterprise and marketization.

\section{Conclusions}

The concept of the school as a learning organization cannot be successfully implemented in Africa because of the generally high level of poverty and where it is being done it further widens the gap between the rich and the poor and makes the school an emblem of disparity.

The poor African child needs to be protected from the intellectually and psychologically damaging consequences and excesses of the free market which a strict application of the concept of the learning organization in its original form/state implies.

While governments must rededicate themselves to greater and better funding of schools, principals (or business managers) and governments must treat schools as social markets, respect human dignity and the right of every person to have a fully and truly human existence. 


\section{References}

2012, Vol. 2, No. 2

Clinton, B (2007) Giving, New York: Random.

Senge P.M (2003) The Fifth Discipline: The Art And Practice of the Learning Organization, London: Century Business.

Garvin, D.A. (2000\} Learning in Action: A Guide to Putting The Learning Organization To Work Boston: Harvard Business School.

Garret, B (2000) The Learning Organization: Developing Democracy At Work London: Happercollins.

Dibella, A.J And Neris E.C (1997) How Organization Learn: An Integrated Strategy for Building Learning Capability Chichester: Jossey-Bass Wiley.

Bloomsbury, (2002|) Business: The Ultimate Resource London: Bloomsbury.

Dess G.G., Lumpkin G.T and Eisner A.B.(2006) Strategic Management: Text and Cases New York: McGraw-Hill.

Wolff L. Schiefelbein E and Valenzuela J. (1994) Improving the Quality of Primary Education In Latin America and the Caribbean: Toward The $21^{\text {st }}$ Century. Washington: World Bank.

Heneveld W and Craig H (1996) Schools Count Washington: The World Bank.

Beare H. Enterprise: The New Metaphor For Schooling in a Post Industrial Society, In Townsend ed (1998) The Primary School in Changing Times London: Routledge.

Townsend H ed (1998) The Primary School in Changing Times, London: Routledge. 